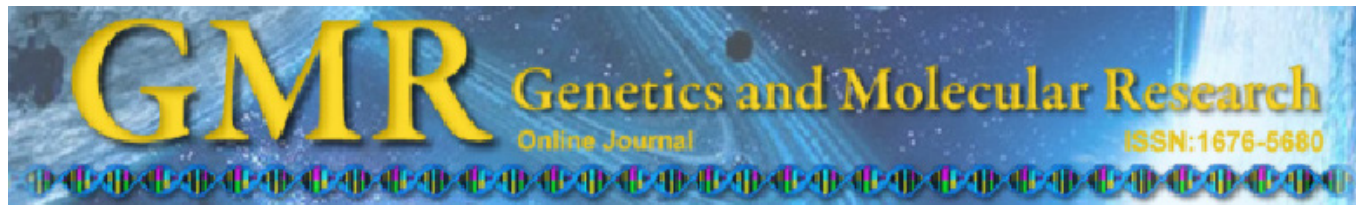

\title{
Single nucleotide polymorphisms in immunity-related genes and their association with mastitis in Chilean dairy cattle
}

\author{
A.M. Carvajal, P. Huircan and A. Lepori \\ Laboratorio de Biotecnología, Instituto de Investigaciones Agropecuarias, \\ Remehue, Osorno, Chile \\ Corresponding author: A.M. Carvajal \\ E-mail: andres.carvajal@inia.cl
}

Genet. Mol. Res. 12 (3): 2702-2711 (2013)

Received September 3, 2012

Accepted March 25, 2013

Published July 30, 2013

DOI http://dx.doi.org/10.4238/2013.July.30.8

\begin{abstract}
Mastitis remains a major cattle disease with great global economic implications. Various approaches are currently employed in attempts to improve understanding of mastitis resistance and develop phenotypic markers for use in breeding programs (e.g., somatic cell score), including QTL discovery, wide-genome association studies, and identification of candidate genes related to immune function. This study evaluated three single nucleotide polymorphisms contained in Toll-like receptor 4 (TLR4) and lactoferrin (LF) genes associated with mastitis traits: TLR4 P-226, TLR4 2021, and LF P-28. Genotyping was performed by restriction fragment length polymorphism-polymerase chain reaction (PCR) and high-resolution melting quantitative PCR from genomic DNA of four dairy cattle breeds (Holstein, Jersey, Montbeliarde, and Overo Colorado) previously classified as healthy, with clinical or with subclinical mastitis. The high-resolution melting quantitative PCR allowed genotyping of each locus and resulted in allele frequencies indicating that all loci were in Hardy-Weinberg equilibrium. The TT genotype of TLR4 2021 was significantly associated with the healthy condition, but no associations with somatic cell score were evident. Further studies are therefore necessary in order
\end{abstract}


to confirm the results of this investigation.

Key words: Dairy cattle; Mastitis; TLR4; Lactoferrin

\section{INTRODUCTION}

Mastitis is the most frequent, complex, and costly disease in dairy herds and causes major economic losses through reductions in milk yield and waste of milk unfit for consumption, resulting in massive antibiotic use and premature culling (Shook, 2006; Halasa et al., 2007). Mastitis is characterized by a mammary gland inflammatory response to contagious or environmental bacteria that invade the mammary gland by penetration through the teat canal (Oviedo-Boyso et al., 2007).

The origin and development of mastitis is influenced by several environmental and genetic factors (Kelm et al., 1997; Bradley, 2002). Furthermore, marked differences in mastitis prevalence among breeds or individuals within breeds suggest that resistance or susceptibility to mastitis, and therefore its prevalence, is influenced by genetic variation (Rupp and Boichard, 2003). However, mastitis resistance or susceptibility is a complex trait that depends on genetic components involved in different signaling pathways and the coordinated activity of various molecules and cells. Several genome-scan studies have identified quantitative trait loci and several molecular markers, such as single nucleotide polymorphisms (SNPs), that are related to mastitis, suggesting that resistance to the condition has a significant genetic component despite its low heritability (Klungland et al., 2001; Heringstad et al., 2003; Holmberg and Andersson-Eklund, 2004; Khatkar et al., 2004; Ogorevc et al., 2009). Indeed, some studies have demonstrated variations or polymorphisms in genes related to immune response that could be associated with mastitis resistance (Detilleux, 2002; Ibeagha-Awemu et al., 2008).

Lactoferrin (LF) is an iron-binding glycoprotein member of the serum transferring protein family (Lacasse et al., 2008). Produced in the mammary gland and immune cells, it is secreted to milk and exerts several functions related to innate immunity, including bacteriostatic properties that protect the udder from infection by pathogens such as Escherichia coli (the most susceptible) and Staphylococcus aureus (Valenti and Antonini, 2005). After a bacterial infection resulting in clinical and subclinical mastitis, mRNA and protein expressions are increased in the mammary gland, with a concomitant increase in the somatic cell count (SCC), suggesting that LF participates in an acutephase response in the mammary gland during mastitis (Hagiwara et al., 2003; Rainard and Riollet, 2006; Griesbeck-Zilch et al., 2008). In general, LF shows immune-modulating and anti-inflammatory properties and operates in synergy with other defense components. For example, the combined treatment of penicillin and LF is a powerful tool against mastitis caused by $S$. aureus (Lacasse et al., 2008). In addition, the LF gene and its promoter are highly polymorphic in several species, including bovines (Seyfert et al., 1996; Li et al., 2004; Daly et al., 2006), and an association between SNPs with reproductive and mastitis traits has been demonstrated (O'Halloran et al., 2009).

Toll-like receptors (TLRs) are membrane proteins mainly expressed in macrophages and dendritic cells (De Schepper et al., 2008). They are the first line of defense against pathogens by sensing their presence through the recognition of specific molecular signatures associated with the invading pathogen, which are collectively known as pathogen-associated molecular patterns (Lu et al., 2008). TLR activation induces the expression of several pro-inflammatory cytokines and chemokines that recruit neutrophils, which triggers the innate immune response and bridges innate and acquired immune responses (Rainard and Riollet, 2006; Lu et al., 2008). TLR4 mainly recognizes 
the conserved lipopolysaccharide and lipoteichoic acid patterns of Gram-negative and -positive bacteria, respectively. The expression of bovine TLR4 is strongly increased in the mammary gland during mastitis caused by S. aureus (Goldammer et al., 2004; Griesbeck-Zilch et al., 2008; Petzl et al., 2008). Like LF, the bovine TLR4 gene is highly polymorphic (White et al., 2003; Mariotti et al., 2009) and some SNPs in the TLR4 gene have been associated with the somatic cell score (SCS) in cattle (Sharma et al., 2006; Wang et al., 2007).

These studies highlight LF and TLR4 as major candidate genes related to mastitis resistance or susceptibility in cattle (Ogorevc et al., 2009). However, further studies are necessary to determine and/or validate clear associations between these SNPs and mastitis traits. The aim of this study was to investigate the associations of two previously identified polymorphisms in TLR4 genes (P-226 and 2021) and one in the LF gene (P-28) with the mastitis condition and the SCS in dairy cattle breeds used in Chile.

\section{MATERIAL AND METHODS}

\section{Samples}

Blood samples were obtained from 167 cows of 4 different breeds (Holstein Friesian, Jersey, Montbeliarde, and Overo Colorado) belonging to commercial herds of the Los Lagos region. Selected animals had at least 3 lactations and were fed mainly by pasture and supplemented with grain and silage over winter. Cows were milked twice a day with automatic milking machines, performing take-offs and pre- and post-milking teat disinfection. The animals were classified by their mammary gland sanitary status: healthy $(\mathrm{H})$, with clinical $(\mathrm{CM})$ or subclinical mastitis (SCM), based on a veterinarian's diagnosis and SCC. The animals were classified as H or SCM based on their observed level of monthly SCC $(\mathrm{H}<200,000$; SCM $>$ $250,000)$ measured over 6 consecutive months. CM was determined based on a veterinarian's diagnosis and the California Mastitis Test score. For statistical analyses, SCC was standardized to SCS, according to the National Mastitis Council (2008).

\section{DNA extraction}

A 3-mL blood sample was obtained from each animal by caudal puncture using a Vacutest system with the anticoagulant ethylenediaminetetraacetic acid, under bioethical approval of the Instituto de Investigaciones Agropecuarias (INIA) and the Comisión Nacional de Investigación Científica y Tecnológica (CONICYT). Genomic DNA was purified using the FavorPrep ${ }^{\mathrm{TM}}$ Blood Genomic DNA Extraction Mini Kit (Favorgene, USA) following manufacturer protocols. DNA was quantified in triplicate by fluorescence in a Rotor-Gene ${ }^{\mathrm{TM}} 6000$ platform (Corbett Life Science, Australia) using the Quant-iT ${ }^{\mathrm{TM}}$ PicoGreen ${ }^{\circledR}$ dsDNA kit (Invitrogen, USA) and its integrity was assessed by gel electrophoresis. Finally, DNA was stored at $-20^{\circ} \mathrm{C}$ for subsequent analyses.

\section{Genotyping}

\section{Restriction fragment length polymorphism-polymerase chain reaction (PCR-RFLP)}

Random samples were genotyped by PCR-RFLP. Briefly, genomic DNA was amplified 
by PCR using specific primers based on published sequence data (GenBank Refs. L19985.1 and DQ839567.1; Table 1). The reactions were carried out in 10- $\mu \mathrm{L}$ volumes containing 50 ng DNA, 1X PCR buffer, $0.25 \mu \mathrm{M}$ of each primer, $0.25 \mathrm{mM}$ of each dNTP, $3 \mathrm{mM} \mathrm{Mg}^{2+}$, and $0.5 \mathrm{U}$ Taq polymerase (Fermentas, USA). The thermal cycling conditions were: an initial denaturation at $95^{\circ} \mathrm{C}$ for $5 \mathrm{~min}$ followed by 40 cycles at $95^{\circ} \mathrm{C}$ for $30 \mathrm{~s}$, annealing for $30 \mathrm{~s}$ (Table 1 ), $72^{\circ} \mathrm{C}$ for $30 \mathrm{~s}$, with a final extension at $72^{\circ} \mathrm{C}$ for $5 \mathrm{~min}$. Digestion of the PCR products was performed overnight at $37^{\circ} \mathrm{C}$ in a final volume of $20 \mu \mathrm{L}$ with specific restriction enzymes ( $2.5 \mathrm{U}$; Table 1$)$ following manufacturer protocols, and was visualized on 3\% agarose gels with GelRed (Biotium, UK) staining.

\begin{tabular}{|c|c|c|c|c|c|}
\hline Gene & SNP & Primer $\left(5^{\prime}-3^{\prime}\right)$ & $\mathrm{Tm}$ & Amplicon size & $\mathrm{RE}$ \\
\hline TLR4 & P-226 & $\begin{array}{l}\text { F: TGTTACTTCAGCCCCTGGTC } \\
\text { R: TCACTTCCTCTCCTCCCGTA }\end{array}$ & $61.7^{\circ} \mathrm{C}$ & $137 \mathrm{bp}$ & HpaII \\
\hline TLR4 & 2021 & $\begin{array}{l}\text { F: GGTAGGGGTCCTAGTCTACAAGTT } \\
\text { R: CCTTTGTCATCTACTCGAGCCA }\end{array}$ & $64.0^{\circ} \mathrm{C}$ & $111 \mathrm{bp}$ & Alw2I \\
\hline LF & P-28 & $\begin{array}{l}\text { F: GGCGCTTATAGGACCACAGG } \\
\text { R: AGAGCCTTCGTTCCGGAGT }\end{array}$ & $63.0^{\circ} \mathrm{C}$ & $103 \mathrm{bp}$ & CvikI1 \\
\hline
\end{tabular}

$\mathrm{F}=$ primer forward $\mathrm{R}=$ primer reverse; $\mathrm{Tm}=$ melting temperature; $\mathrm{RE}=$ restriction enzyme.

\section{High-resolution melting quantitative PCR (qPCR-HRM)}

Genotyping of all samples was carried out by qPCR-HRM, a rapid mutation scanning assay that detects sequence variation within the PCR products according to their dissociation behavior as they transition from double-stranded to single-stranded DNA with increasing temperature. Dissociation behavior is measured by the release of the saturating double-stranded DNA dye (Montgomery et al., 2007). Briefly, genomic DNA (10 ng) was amplified in a RotorGene $^{\mathrm{TM}} 6000$ platform (Corbett Life Science) in $15-\mu \mathrm{L}$ volumes using the Sensimix HRM kit ( $3 \mathrm{mM} \mathrm{Mg}^{2+}$, dNTP mix; Bioline, UK) including EvaGreen and $0.25 \mu \mathrm{M}$ of each primer. The thermal cycling conditions were as follows: initial denaturation at $95^{\circ} \mathrm{C}$ for $10 \mathrm{~min}$ followed by 40 cycles at $95^{\circ} \mathrm{C}$ for $15 \mathrm{~s}$, annealing for $30 \mathrm{~s}$ (Table 1 ) and $72^{\circ} \mathrm{C}$ for $10 \mathrm{~s}$. The fluorescence was measured at $510 \mathrm{~nm}$ (green channel) after the extension step. After amplification, the melting analysis was immediately performed by heating the reaction mixture from $75^{\circ}$ to $90^{\circ} \mathrm{C}$ at a rate of $0.1{ }^{\circ} \mathrm{C} / \mathrm{s}$ and measuring the fluorescence at the HRM channel. All samples were assayed in triplicate. To assign genotypes to the melting curves, samples previously genotyped by PCR-RFLP were used as positive controls. In addition, amplicons were routinely checked for the presence of nonspecific products by electrophoresis on agarose gel.

\section{Genetic analyses}

After genotyping, genetic and allelic frequencies of the three SNPs were calculated by simple counts, and Hardy-Weinberg equilibrium (HWE) was determined using a chi-square test at $\mathrm{P}<0.05$ (Falconer and MacKay, 1996).

\section{Statistical analyses}

To test the association between the three individual SNPs and sanitary status (H, CM, 
or SCM), a multinomial logistic or probit regression model was used since sanitary status was an ordered factor response. The genotype of each SNP was analyzed as a fixed effect. To estimate the independent association between SCS and the SNPs, the clinical mastitis status was excluded since determination of this status was based on the clinical manifestation of the condition and not on the SCC. The filtered data were analyzed with generalized linear models using R (R Development Core Team, 2012) programming and statistical language.

\section{RESULTS AND DISCUSSION}

\section{Genotyping}

Allelic variants for each polymorphism were determined by PCR-RFLP in random samples chosen from different breeds. Figure 1 shows the electrophoretic pattern of specific amplified products for TLR4 P-226 (137 bp), TLR4 2021 (111 bp), and LF P-28 (103 bp) and the digested fragments after enzyme restriction. Genotyped samples were used as positive controls in the qPCR-HRM assay.

As an example, Figure 2 shows the amplification of a fragment of the TLR4 gene containing the SNP 2021. The cycle threshold was 22.5 with all samples reaching the plateau in cycle 34 (Figure 2A). The melting analyses showed amplification of only one fragment with three different curves with a specific melting temperature (Figure 2B), which was confirmed by electrophoresis (data not shown). The curves corresponding to the HRM and fluorescence standards were distinguishable for each variant with high confidence (CC, $\mathrm{CT}$, and TT; Figure 2C and D) according to positive controls genotyped by PCR-RFLP. Homozygous samples (CC and TT) could be genotyped by an absolute change in Tm, while heterozygous (CT) samples could be identified through changes in the shape of the melting curves (Figure 2C). This pattern of three different curves for the 3 alleles was also obtained for the other two polymorphisms.

\section{Genetic and statistical results}

Table 2 summarizes the allele frequencies for each polymorphism. The analyses of the chi-square test showed that all loci were in $\operatorname{HWE}(\mathrm{P}>0.05)$. The first polymorphism evaluated was the SNP TLR4 P-226 (C > G), which is located in the 5'-untranslated region of the TLR4 gene over putative DNA binding sites, such as c-Ets-1, MZF1, and ADR1, and close to a GATA box (Sharma et al., 2006), suggesting an important role of this SNP in the transcriptional regulation of TLR4 mRNA (Sharma et al., 2008). At this locus, the most frequent variant observed was the $\mathrm{C}$ allele. However, in Holstein, the predominant allele was $\mathrm{G}(56 \%)$. This variant $(\mathrm{G})$ was also predominant in a Canadian Holstein bull population studied by Sharma et al. (2006), who also found an association between the C allele, higher SCS, and higher lactation persistence. This SNP has also been implicated in the susceptibility to paratuberculosis (Ruiz-Larrañaga et al., 2011). Although SCS has previously been genetically correlated with clinical mastitis (albeit not definitively) and has been used as an indicator of mastitis and exploited for selecting animals with mastitis resistance (Koivula et al., 2005), no association between SCS and genotype or sanitation status was found in our analyses. 

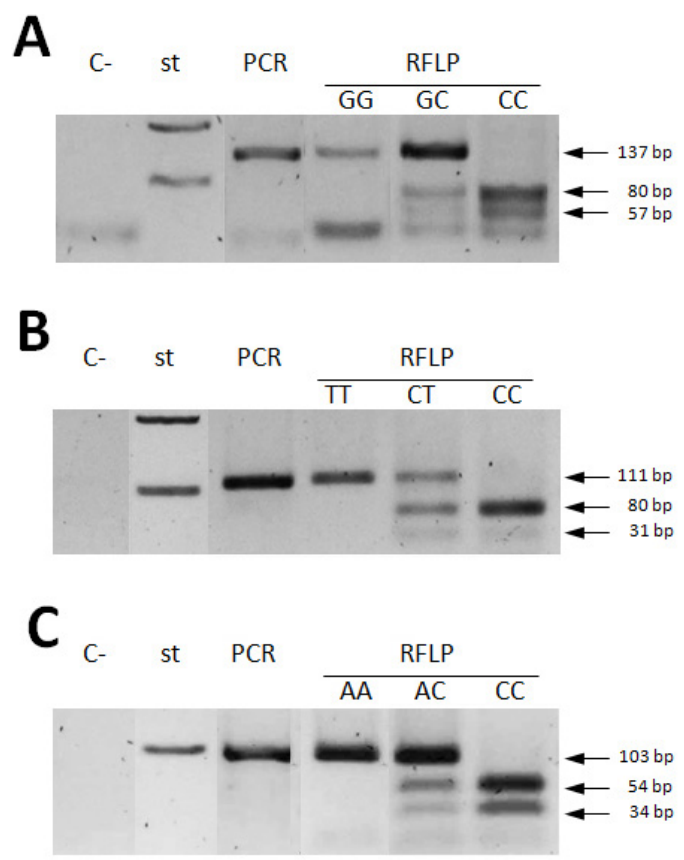

Figure 1. Genotyping of TLR4 and lactoferrin polymorphisms by PCR-RFLP. A. TLR4 P-226. B. TLR4 2021. C. LF P-28. C- = negative control; st $=$ molecular weight; PCR = amplicon.
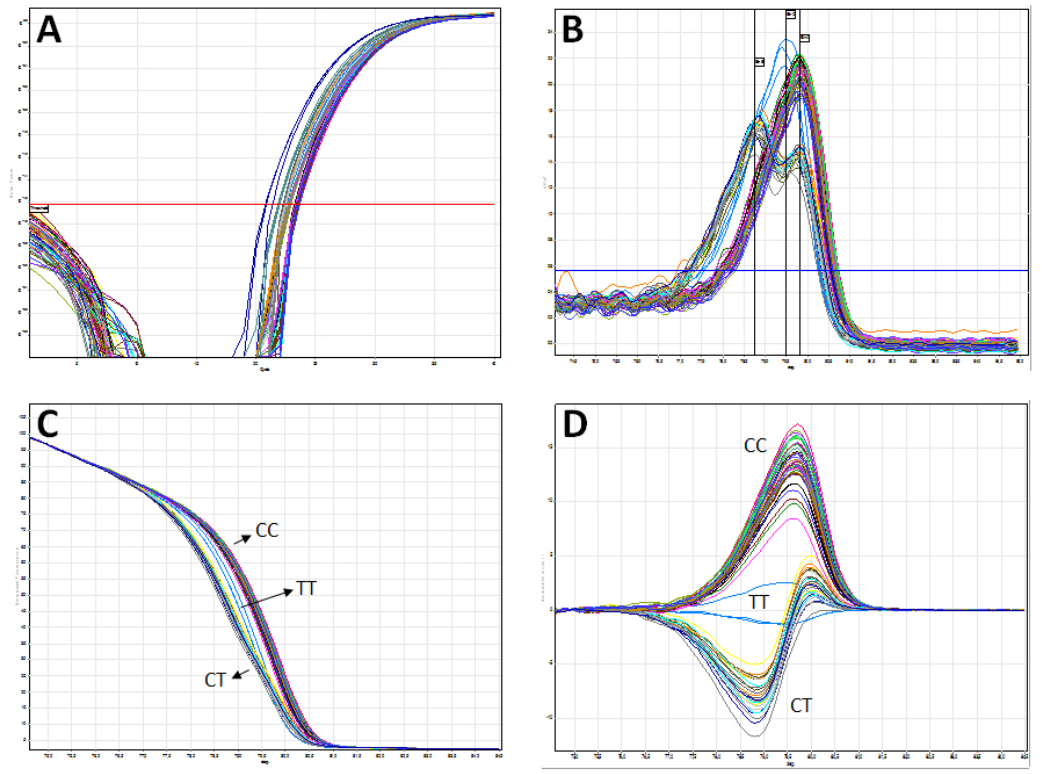

Figure 2. Genotyping of the TLR4 2021 polymorphism by qPCR-HRM. A. Curves of amplification; B. melting; C. normalized HRM; D. difference of fluorescence. CC, CT and TT: genotypes. Three patterns were obtained for HRM curves and the genotype assignments agreed with PCR-RFLP results. 
Table 2. Allele frequencies and Hardy-Weinberg equilibrium for TLR4 and lactoferrin polymorphisms in 4 dairy cattle breeds.

\begin{tabular}{|c|c|c|c|c|c|c|c|c|c|c|}
\hline \multirow[t]{2}{*}{ Breed } & \multirow[t]{2}{*}{$\mathrm{N}$} & \multicolumn{3}{|c|}{ TLR4 P-226 } & \multicolumn{3}{|c|}{ TLR4 2021} & \multicolumn{3}{|c|}{ LF P-28 } \\
\hline & & $\mathrm{C}$ & G & $\chi^{2}$ & $\mathrm{C}$ & $\mathrm{T}$ & $\chi^{2}$ & A & $\mathrm{C}$ & $\chi^{2}$ \\
\hline Holstein & 62 & 0.44 & 0.56 & 0.17 & 0.88 & 0.12 & 1.17 & 0.65 & 0.35 & 1.00 \\
\hline Jersey & 28 & 0.79 & 0.21 & 0.10 & 0.43 & 0.57 & 0.78 & 0.45 & 0.55 & 0.20 \\
\hline Montbeliarde & 41 & 0.55 & 0.45 & 1.09 & 0.89 & 0.11 & 0.62 & 0.61 & 0.39 & 0.25 \\
\hline Overo Colorado & 36 & 0.72 & 0.28 & 1.03 & 0.88 & 0.13 & 0.74 & 0.83 & 0.17 & 1.44 \\
\hline All breeds & 167 & 0.59 & 0.41 & $4.29^{\mathrm{a}}$ & 0.81 & 0.19 & 0.68 & 0.64 & 0.36 & 0.01 \\
\hline
\end{tabular}

$\mathrm{A}, \mathrm{C}, \mathrm{G}$, and $\mathrm{T}=$ alleles; $\chi^{2}=$ chi-square test. ${ }^{\mathrm{a}} \mathrm{P}<0.05$.

Polymorphism TLR4 $2021(\mathrm{C}>\mathrm{T})$ is a nonsynonymous SNP in exon 3 that corresponds to an amino acid change in the predicted transmembrane-cytoplasmic domain (White et al., 2003). For this SNP, the most frequent variant found in Holstein, Montbeliarde, and Overo Colorado breeds was the C allele (89\%). By contrast, in Jersey cattle, the T allele was predominant $(57 \%)$. In addition, this was the only breed carrying the TT genotype. These frequencies were similar to those reported by Beecher et al. (2010), where the rare TT genotype was found in Jersey but was almost absent in Holstein and was undetected in the Montbeliarde and Norwegian Red breeds. In addition, they associated the predominant $\mathrm{C}$ allele with a reduced percentage of milk protein in late lactation but not with SCS, and also found an association between the CT genotype and higher percentages of milk fat. These observations appear to corroborate our data, which demonstrate the presence of the TT genotype in Jersey only, a breed characterized by high levels of milk solids, including fat percentage. In our study, we did not find a significant effect of genotype on SCS $(P>0.05)$. With respect to the influence of SNPs on sanitary status condition, we found a significant effect $(\mathrm{P}=0.028)$ only for animals carrying the TT genotype, which also had the highest proportion (75.2\%) of individuals in the $\mathrm{H}$ condition (Figure 3). Further studies with a larger number of Jersey cows are necessary to confirm this potential correlation. On the other hand, Sharma et al. (2006) demonstrated an association between the $\mathrm{C}$ allele (the most frequent) with lower SCS and higher lactation persistence in Holstein cows.

Polymorphism LF P-28 $(\mathrm{A}>\mathrm{C})$ has been the most frequently encountered SNP in the bovine lactoferrin promoter region, and is located adjacent to the TATA box, a major transcription factor recognition site (Daly et al., 2006), suggesting its potential role in regulating LF transcription (Bahar et al., 2011). In our study, the most frequent variant present in Holstein, Montbeliarde, and Overo Colorado breeds was the A allele. In Jersey, the C allele was predominant (55\%) and the CC genotype was not detected in the Overo Colorado breed, probably due to the small sample size. Likewise, this major allele (A) was also reported by O'Halloran et al. (2009), who also found a tendency for it to be associated with higher SCS in the progeny of Holstein sires (O'Halloran et al., 2010). As for TLR4 P-226, we did not find any association between genotypes of LF P-26 and SCS or sanitation status.

In summary, we found a significant effect of the TT genotype of TLR4 2021 on the $\mathrm{H}$ condition but not on SCS. Our criteria for classifying the animals as H, CM, or SCM were based on altered signs in mammary glands and milk, and monthly SCC counts. Since the SCC does not always reflect mammary condition, specially regarding CM (Rupp and Boichard, 2003), we performed an in vitro culture and PCR to identify the bacterial pathogens present in milk samples of each cow. Milk samples from $\mathrm{H}$ condition individuals were mostly 
pathogen-free, while CM or SCM individuals contained major bacteria such as S. aureus, coagulase-negative Staphylococcus, and Streptococcus uberis (data not shown). Several factors are known to influence SCC, but its correlation with bacterial infection has been estimated to be particularly high. The results of this study suggest that other factors can be implicated in the relationship between SCC and the mastitis condition, which may explain the lack of association observed. Moreover, several candidate genes on almost all chromosomes have been reported to be associated with CM and SCS, some of which have key functions related to the immune system, such as MHC class II DRB3 (Sharif et al., 1998; Rupp and Boichard, 2003; Ogorevc et al., 2009). Finally, this study examined a small population, which may have limited the results of statistical analyses. Future studies should attempt to increase sample sizes in order to clarify the associations between SCC, SNPs, and mastitis.

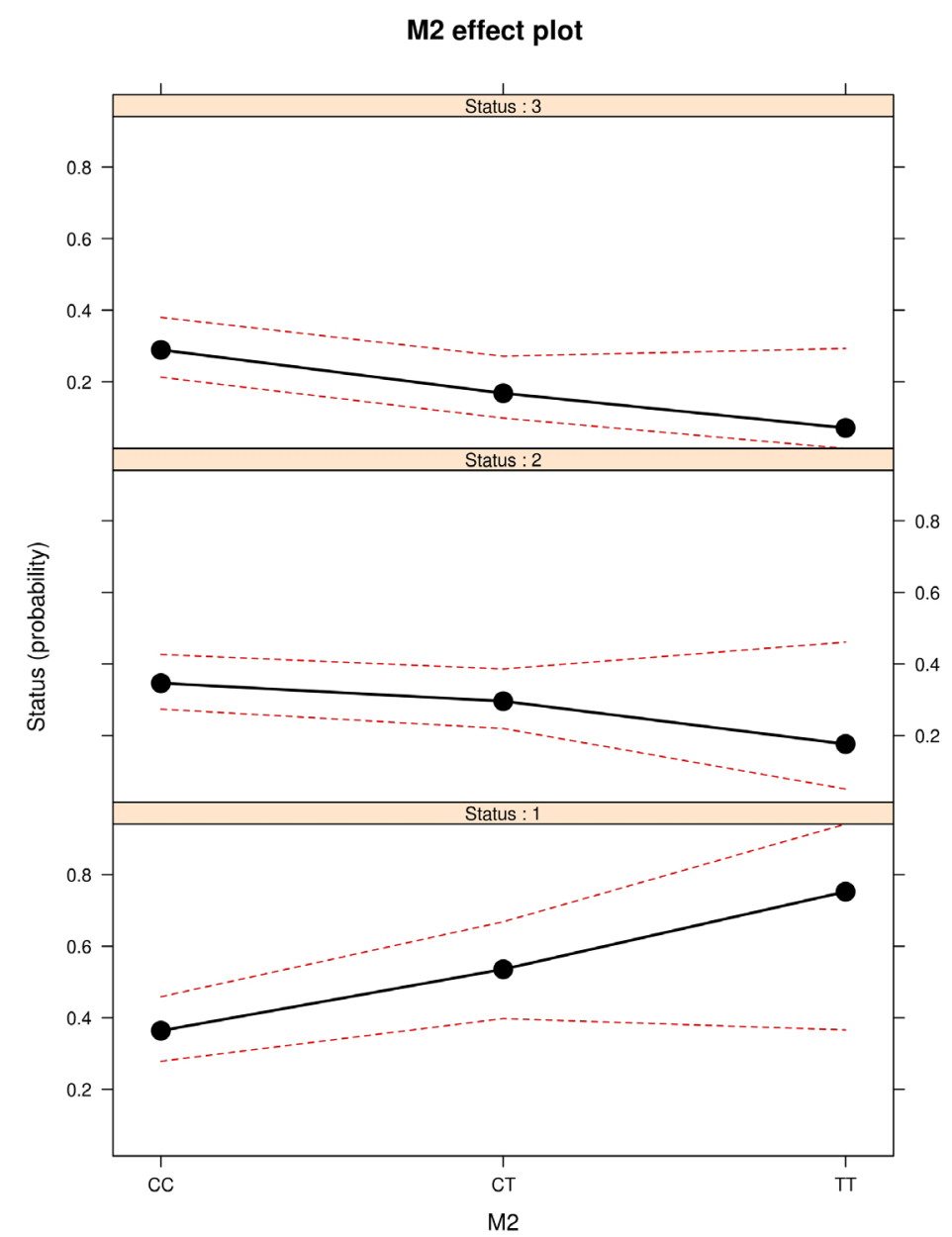

Figure 3. Proportional odds logistic regression of the TLR4 2021 polymorphism (M2) over status condition. Status 1,2 and 3: healthy, subclinical and clinical mastitis conditions, respectively. 


\section{CONCLUSIONS}

Mastitis remains a major cattle disease with great economic impacts around the world, including in Chile. Several candidate genes related to immune function have been associated with mastitis resistance and with SCS, but broad validation of these promising results is still needed. In this study, we evaluated three previously identified SNPs contained in TLR-4 and LF genes associated with mastitis traits in dairy cattle: TLR4 P-226, TLR4 2021, and LF P-28. Each locus was successfully genotyped by qPCR-HRM, and allele frequencies indicated that all loci were in HWE. A significant effect of the TT genotype of TLR4 2021 on the H condition was observed; however, no associations with SCS were evident. Further studies are therefore necessary in order to confirm these associations.

\section{ACKNOWLEDGMENTS}

The authors thank the milk producers and the laboratory staff of the Udder Health Company for their assistance in sampling. Research supported by the Fondo Nacional de Desarrollo Científico y Tecnológico (FONDECYT, Project 11090359) to A.M. Carvajal.

\section{REFERENCES}

Bahar B, O'Halloran F, Callanan MJ, McParland S, et al. (2011). Bovine lactoferrin (LTF) gene promoter haplotypes have different basal transcriptional activities. Anim. Genet. 42: 270-279.

Beecher C, Daly M, Childs S, Berry DP, et al. (2010). Polymorphisms in bovine immune genes and their associations with somatic cell count and milk production in dairy cattle. BMC Genet. 11: 99.

Bradley A (2002). Bovine mastitis: an evolving disease. Vet. J. 164: 116-128.

Daly M, Ross P, Giblin L and Buckley F (2006). Polymorphisms within the lactoferrin gene promoter in various cattle breeds. Anim. Biotechnol. 17: 33-42.

De Schepper S, De KA, Bannerman DD, Paape MJ, et al. (2008). The toll-like receptor-4 (TLR-4) pathway and its possible role in the pathogenesis of Escherichia coli mastitis in dairy cattle. Vet. Res. 39: 5.

Detilleux JC (2002). Genetic factors affecting susceptibility of dairy cows to udder pathogens. Vet. Immunol. Immunopathol. 88: $103-110$

Falconer DS and MacKay TFC (1996). Introduction to Quantitative Genetics. Longman Group, Harlow.

Goldammer T, Zerbe H, Molenaar A, Schuberth HJ, et al. (2004). Mastitis increases mammary mRNA abundance of betadefensin 5, toll-like-receptor 2 (TLR2), and TLR4 but not TLR9 in cattle. Clin. Diagn. Lab. Immunol. 11: 174-185.

Griesbeck-Zilch B, Meyer HH, Kuhn CH, Schwerin M, et al. (2008). Staphylococcus aureus and Escherichia coli cause deviating expression profiles of cytokines and lactoferrin messenger ribonucleic acid in mammary epithelial cells. $J$. Dairy Sci. 91: 2215-2224.

Hagiwara S, Kawai K, Anri A and Nagahata H (2003). Lactoferrin concentrations in milk from normal and subclinical mastitic cows. J. Vet. Med. Sci. 65: 319-323.

Halasa T, Huijps K, Osteras O and Hogeveen H (2007). Economic effects of bovine mastitis and mastitis management: a review. Vet. $Q 29: 18-31$.

Heringstad B, Klemetsdal G and Steine T (2003). Selection responses for clinical mastitis and protein yield in two Norwegian dairy cattle selection experiments. J. Dairy Sci. 86: 2990-2999.

Holmberg M and Andersson-Eklund L (2004). Quantitative trait loci affecting health traits in Swedish dairy cattle. $J$. Dairy Sci. 87: 2653-2659.

Ibeagha-Awemu EM, Kgwatalala P, Ibeagha AE and Zhao X (2008). A critical analysis of disease-associated DNA polymorphisms in the genes of cattle, goat, sheep, and pig. Mamm. Genome 19: 226-245.

Kelm SC, Detilleux JC, Freeman AE, Kehrli ME, Jr., et al. (1997). Genetic association between parameters of inmate immunity and measures of mastitis in periparturient Holstein cattle. J. Dairy Sci. 80: 1767-1775.

Khatkar MS, Thomson PC, Tammen I and Raadsma HW (2004). Quantitative trait loci mapping in dairy cattle: review and meta-analysis. Genet. Sel. Evol. 36: 163-190. 
Klungland H, Sabry A, Heringstad B, Olsen HG, et al. (2001). Quantitative trait loci affecting clinical mastitis and somatic cell count in dairy cattle. Mamm. Genome 12: 837-842.

Koivula M, Mantysaari EA, Negussie E and Serenius T (2005). Genetic and phenotypic relationships among milk yield and somatic cell count before and after clinical mastitis. J. Dairy Sci. 88: 827-833.

Lacasse P, Lauzon K, Diarra MS and Petitclerc D (2008). Utilization of lactoferrin to fight antibiotic-resistant mammary gland pathogens. J. Anim. Sci. 86: 66-71.

Li GH, Zhang Y, Sun DX and Li N (2004). Study on the polymorphism of bovine lactoferrin gene and its relationship with mastitis. Anim. Biotechnol. 15: 67-76.

Lu YC, Yeh WC and Ohashi PS (2008). LPS/TLR4 signal transduction pathway. Cytokine 42: 145-151.

Mariotti M, Williams JL, Dunner S, Valentini A, et al. (2009). Polymorphisms within the Toll-like receptor (TLR)-2, -4, and -6 genes in cattle. Diversity 1: 7-18.

Montgomery J, Wittwer CT, Palais R and Zhou L (2007). Simultaneous mutation scanning and genotyping by highresolution DNA melting analysis. Nat. Protoc. 2: 59-66.

National Mastitis Council (NMC) (2008). The gestation and birth of Somatic Cell Score. Available at [http://nmconline. org/articles/SCSReview.htm]. Accessed September 2011.

O’Halloran F, Bahar B, Buckley F, O'Sullivan O, et al. (2009). Characterisation of single nucleotide polymorphisms identified in the bovine lactoferrin gene sequences across a range of dairy cow breeds. Biochimie 91: 68-75.

O'Halloran F, Berry DP, Bahar B, Howard DJ, et al. (2010). Polymorphisms in the bovine lactoferrin promoter are associated with reproductive performance and somatic cell count. J. Dairy Sci. 93: 1253-1259.

Ogorevc J, Kunej T, Razpet A and Dovc P (2009). Database of cattle candidate genes and genetic markers for milk production and mastitis. Anim. Genet. 40: 832-851.

Oviedo-Boyso J, Valdez-Alarcon JJ, Cajero-Juarez M, Ochoa-Zarzosa A, et al. (2007). Innate immune response of bovine mammary gland to pathogenic bacteria responsible for mastitis. J. Infect. 54: 399-409.

Petzl W, Zerbe H, Günther J, Yang W, et al. (2008). Escherichia coli, but not Staphylococcus aureus triggers an early increased expression of factors contributing to the innate immune defense in the udder of the cow. Vet. Res. 39: 18.

R Development Core Team (2012). R: A Language and Environment for Statistical Computing. R Foundation for Statistical Computing, Vienna.

Rainard P and Riollet C (2006). Innate immunity of the bovine mammary gland. Vet. Res. 37: 369-400.

Ruiz-Larrañaga O, Manzano C, Iriondo M, Garrido JM, et al. (2011). Genetic variation of toll-like receptor genes and infection by Mycobacterium avium ssp. paratuberculosis in Holstein-Friesian cattle. J. Dairy Sci. 94: 3635-3641.

Rupp R and Boichard D (2003). Genetics of resistance to mastitis in dairy cattle. Vet. Res. 34: 671-688.

Seyfert HM, Henke M, Interthal H, Klussmann U, et al. (1996). Defining candidate genes for mastitis resistance in cattle: the role of lactoferrin and lysozyme. J. Anim. Breed. Genet. 113: 269-276.

Sharif S, Mallard BA, Wilkie BN, Sargeant JM, et al. (1998). Associations of the bovine major histocompatibility complex DRB3 (BoLA-DRB3) alleles with occurrence of disease and milk somatic cell score in Canadian dairy cattle. Anim. Genet. 29: 185-193.

Sharma BS, Leyva I, Schenkel F and Karrow NA (2006). Association of toll-like receptor 4 polymorphisms with somatic cell score and lactation persistency in Holstein bulls. J. Dairy Sci. 89: 3626-3635.

Sharma BS, Mount J and Karrow NA (2008). Functional characterization of a single nucleotide polymorphism in the 5, UTR region of the bovine toll-like receptor 4 gene. Dev. Biol. 132: 331-336.

Shook GE (2006). Major advances in determining appropriate selection goals. J. Dairy Sci. 89: 1349-1361.

Valenti P and Antonini G (2005). Lactoferrin: an important host defence against microbial and viral attack. Cell Mol. Life Sci. 62: 2576-2587.

Wang X, Xu S, Gao X, Ren H, et al. (2007). Genetic polymorphism of TLR4 gene and correlation with mastitis in cattle. J. Genet. Genomics 34: 406-412.

White SN, Taylor KH, Abbey CA, Gill CA, et al. (2003). Haplotype variation in bovine Toll-like receptor 4 and computational prediction of a positively selected ligand-binding domain. Proc. Natl. Acad. Sci. U. S. A. 100: 1036410369 . 